\title{
Genetic and adaptive trait variation in seedlings of European beech provenances from Northern Germany
}

\author{
Markus Müller ${ }^{1 *}$, Reiner Finkeldey ${ }^{1,2}$ \\ ${ }^{1}$ University of Goettingen, Faculty for Forest Sciences and Forest Ecology, Forest Genetics and Forest Tree Breeding, \\ Büsgenweg 2, 37077 Göttingen, Germany; \\ 2 University of Kassel, Mönchebergstraße 19, 34109 Kassel* $^{*}$
}

Corresponding author: Markus Müller, E-mail: mmuellef@gwdg.de

\begin{abstract}
European beech (Fagus sylvatica L.) will most likely be threatened by climate change. Therefore, more knowledge of its adaptation potential to changing environmental conditions is required. Several studies showed differences in adaptive traits for beech populations from across Europe, but there is also growing evidence for microevolutionary processes occurring within short geographic distances in this species, or even a lack of local adaptation. Hence, a more regional perspective for adaptation research in beech might be appropriate. Here, we investigated the performance (height, height increment and mortality) and genetic structure based on microsatellite markers of 2400 beech seedlings from provenances growing along a temperature and precipitation gradient in Northern Germany in a common garden experiment. Differences for all traits were found among provenances. Provenances from lower precipitation areas did not perform better than provenances from higher precipitation areas at the common garden site, which was located near the lower precipitation limit of beech. Further, neighboring provenances growing on either sandy or loamy soils showed more different adaptive trait variation than distant provenances. We detected minor genetic structure among provenances and a high genetic diversity within them. Thus, small-scale adaptive trait variation in beech can occur, despite low but significant genetic population structure among provenances.
\end{abstract}

Keywords: Mortality, adaptive traits, climate change, genetic diversity

\section{Introduction}

European beech (Fagus sylvatica L.) is a foundation tree species of various forest ecosystems and covers a large continuous geographic range in Europe (Knapp et al. 2008). Its importance will even increase in the future, due to current forest conversion programs in which pure conifer stands are converted into pure beech stands or mixed deciduous stands including beech (Tarp et al. 2000, Scharnweber et al. 2011). Nevertheless, climate change-related alterations of productivity or species distribution have already been observed for this species (Peñuelas and Boada 2003, Charru et al. 2010), and further range shifts of beech have been predicted (Meier et al. 2011, Hanewinkel et al. 2013). Even in the center of its distribution range, beech seems already be negatively affected by climate change (Knutzen et al. 2017). Several studies detected differences among beech provenances from across Europe in adaptive traits such as drought tolerance, frost resistance, or bud burst timing (von Wühlisch et al. 1995, Višnjić and Dohrenbusch 2004, Robson et al. 2012). For instance, it was shown that provenances from Central and Southeast Europe are more frost resistant than provenances from Southern Europe (Višnjić and Dohrenbusch 2004), and provenances from dryer environments are better adapted to drought than provenances from moister environments (Rose et al. 2009, Dounavi et al. 2016). Nevertheless, recent studies showed that microevolutionary processes in beech can occur within short geographic distances (Pluess and Weber 2012, Pluess et al. 2016). Indications for water availability-related adaptation in neighboring beech populations, for instance, were found by Pluess and Weber (2012), despite high gene flow. Also, there can be a lack of local adaptation in beech (Hofmann et al. 2015). Therefore, more knowledge about the regional adaptive trait and genetic differentiation of beech is required.

Here, we investigated the genetic diversity and performance of transferred seedlings of six beech provenances in Northern Germany. Beech provenances from a temperature and 
precipitation gradient were selected and a common garden experiment comprising 2400 seedlings was placed on the dry end of the gradient with a mean annual precipitation close to the lower limit of beech. Hence, the performance (measured as height, height increment, and mortality) of genetic material transferred from high to low precipitation areas could be evaluated. Furthermore, neighboring provenances growing on either sandy or loamy soils were selected along the gradient to cover variation in water storage capacity and to investigate small-scale differentiation in beech provenances.

We tested the hypotheses that (I) there is adaptive trait variation among the investigated beech provenances, with differences on the local level, (II) provenances from lower precipitation areas perform better than provenances from higher precipitation areas under low precipitation conditions, (III) all investigated beech provenances show a high genetic diversity, and (IV) low but significant genetic structure is detectable among provenances.

\section{Material and Methods}

\section{Study sites}

Beech provenances from four different study sites in Northern Germany were selected (Fig. 1). They were jointly investigated by the collaborative project "KLIFF" (climate impact and adaptation research in Lower Saxony; http://www.kliff-niedersachsen.de), and have previously been described by and Müller et al. (2015). At three of these study sites (Calvörde, Göhrde, and Unterlüß) two provenances with different soil properties were selected to cover variation in water storage capacity: one provenance on a sandy soil, hereafter termed "sand", and one provenance on a loam-richer soil, hereafter termed "loam". The different provenances were the following: Calvörde sand (CS), Calvörde loam (GL), Göhrde sand (GS), Göhrde loam (GL), Unterlüß sand (US), Unterlüß loam (UL). The provenance UL was not included in the common garden experiment (see below) due to an insufficient number of seedlings for this provenance. Additionally, a provenance in the Harz Mountains (Harz, (Ha)) near the village Bad Grund was investigated to include a provenance growing under high mean annual precipitation and low mean annual temperatures. All provenances were 2009 between 97 (CS) and 142 years (GL) old and either pure beech stands or beech stands with mixture of a few oak trees. The provenances were located at elevations of $72 \mathrm{~m}$ a.s.l. $(\mathrm{CL})$ to $458 \mathrm{~m}$ a.s.l. (Ha). Mean annual temperatures ranged from $7.2^{\circ} \mathrm{C}(\mathrm{Ha})$ to $9.2^{\circ} \mathrm{C}(\mathrm{CS})$ and mean annual precipitation ranged from $543 \mathrm{~mm}(\mathrm{CL})$ to $1,170 \mathrm{~mm}(\mathrm{Ha})$ (Table. 1). Geographic distance among provenances ranged from $2.2 \mathrm{~km}$ between CL and CS to $154.0 \mathrm{~km}$ between GS and Ha (Supplementary Material 1).

\section{Common garden experiment}

In total, 707 adult trees of the beech provenances described above have been investigated in a previous study (Seifert 2012). The trees were randomly distributed throughout the provenances. To establish a common garden experiment with

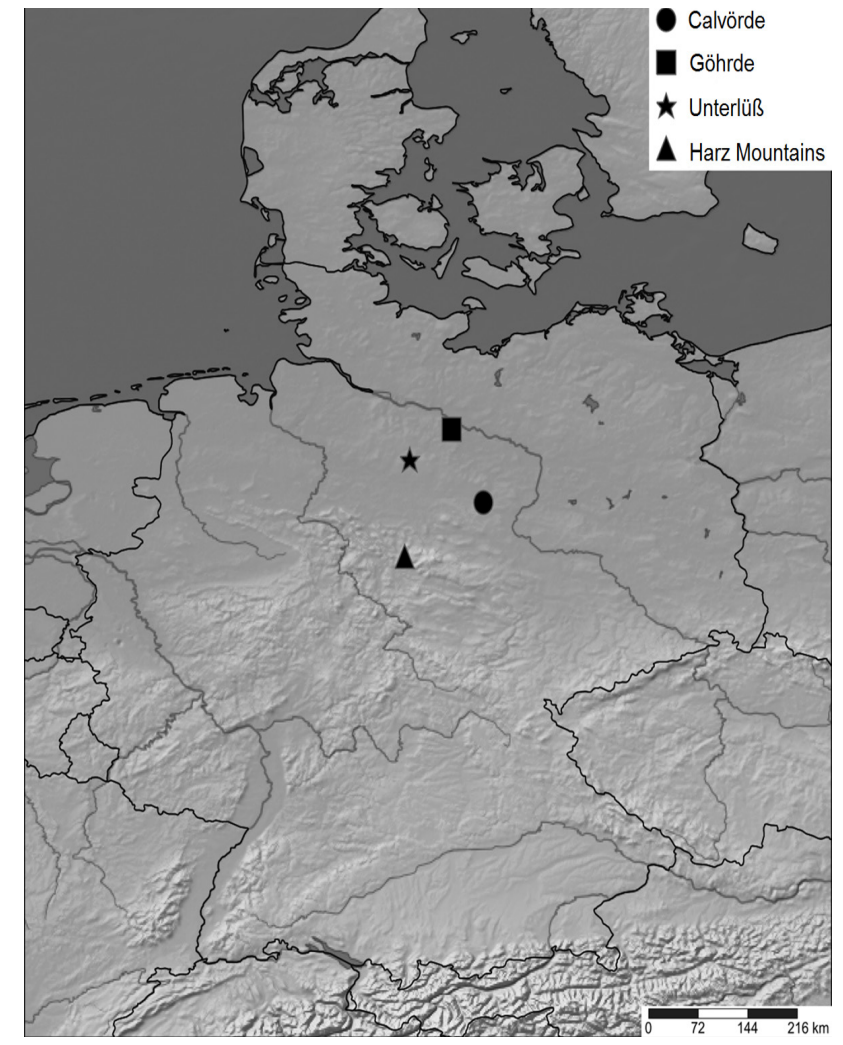

Fig. 1 Location of the four study sites Calvörde, Göhrde, Unterlüß and Harz Mountains. The map was created using SimpleMappr (Shorthouse 2010)

offspring of these provenances, 100 beechnuts from beneath each previously sampled tree were collected in fall 2009. Beechnuts from the sampled trees were not kept separate within provenances, hence they cannot be assigned to single mother trees. Seedlings out of these beechnuts were raised in a greenhouse as described by Seifert (2012). The seedlings of the different provenances were randomly placed in the greenhouse. The seedlings were planted out in a common garden experiment in fall 2010 using a randomized complete block design with four replications as described in Müller et al. (2015). Briefly, from each provenance 400 vital individuals of the established seedlings in the greenhouse were randomly selected and planted out in the beech stand Calvörde sand. Each block contained 600 seedlings. In each block, each provenance was planted in 20 rows (with $14 \mathrm{~cm}$ of distance between them) each containing 5 seedlings (with $11 \mathrm{~cm}$ of distance between them). The seedlings were protected against damage by deer.

\section{Measurements and observations of seedling adaptive traits}

Height of all living seedlings was measured in fall 2010 (planting), 2011 and 2012. The height was measured to $0.5 \mathrm{~cm}$ accuracy from the ground to the beginning of the terminal bud along the stem axis of each seedling. Seedlings with damaged terminal shoots were excluded from the analysis (in total, 252 individuals (zero in 2010; 177 in 2011; 252 in 2012)). Seedling 
Table 1

Characteristics of the seed source beech provenances

\begin{tabular}{|c|c|c|c|c|c|c|}
\hline Provenance & $\begin{array}{l}\text { Calvörde } \\
\text { sand (CS) }\end{array}$ & $\begin{array}{l}\text { Calvörde } \\
\text { loam (CL) }\end{array}$ & $\begin{array}{c}\text { Göhrde } \\
\text { sand (GS) }\end{array}$ & $\begin{array}{c}\text { Göhrde } \\
\text { loam (GL) }\end{array}$ & $\begin{array}{l}\text { Unterlüß } \\
\text { sand (US) }\end{array}$ & $\begin{array}{l}\text { Harz Mountains } \\
(\mathrm{Ha})\end{array}$ \\
\hline \multirow{2}{*}{ Position } & $52^{\circ} 23^{\prime} \mathrm{N}$ & $52^{\circ} 24^{\prime} \mathrm{N}$ & $53^{\circ} 09^{\prime} \mathrm{N}$ & $53^{\circ} 07^{\prime} \mathrm{N}$ & $52^{\circ} 50^{\prime} \mathrm{N}$ & $51^{\circ} 49^{\prime} \mathrm{N}$ \\
\hline & $11^{\circ} 17^{\prime} \mathrm{E}$ & $11^{\circ} 16^{\prime} \mathrm{E}$ & $10^{\circ} 52^{\prime} \mathrm{E}$ & $10^{\circ} 49^{\prime} \mathrm{E}$ & $10^{\circ} 19^{\prime} \mathrm{E}$ & $10^{\circ} 15^{\prime} \mathrm{E}$ \\
\hline $\begin{array}{l}\text { Mean temperature }{ }^{1} \\
{\left[{ }^{\circ} \mathrm{C}\right]}\end{array}$ & $9.2 / 14.5$ & $9.1 / 14.5$ & $8.7 / 13.9$ & $8.7 / 13.8$ & $8.5 / 13.6$ & $7.2 / 12.4$ \\
\hline $\begin{array}{l}\text { Mean precipitation }{ }^{1} \\
{[\mathrm{~mm}]}\end{array}$ & $544 / 294$ & $543 / 294$ & $665 / 347$ & $675 / 349$ & $766 / 374$ & $1170 / 660$ \\
\hline 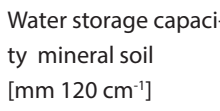 & $81^{\mathrm{a}}$ & $140^{\mathrm{a}}$ & $80^{\mathrm{a}}$ & $78^{\mathrm{a}}$ & $79^{a}$ & na \\
\hline Stand age [years] & $97^{a}$ & $131^{\mathrm{a}}$ & $133^{\mathrm{a}}$ & $142^{\mathrm{a}}$ & $115^{\mathrm{a}}$ & $136^{\mathrm{b}}$ \\
\hline Elevation [m a.s.I.] & $75^{\mathrm{a}}$ & $72^{\mathrm{a}}$ & $85^{\mathrm{a}}$ & $85^{\mathrm{a}}$ & $117^{\mathrm{a}}$ & $458^{b}$ \\
\hline
\end{tabular}

height increment was calculated by subtracting the seedling height at planting (2010) from the seedling height in fall 2012 for each individual in the common garden experiment. The mortality of the seedlings (death of the whole seedling) was visually assessed and recorded in early summer 2011, 2012 and 2013.

\section{Selection of seedlings for genotyping}

SSR-genotyping of seedlings was conducted to determine their neutral genetic variation. For that, 100 individuals per provenance (i.e., 25 within each block) were randomly selected for genotyping (in total, 600 seedlings). Microsatellite data for the adult provenances were provided by Seifert (Seifert 2012).

\section{DNA isolation}

In July 2010, one leaf per seedling from the common garden experiment was sampled and stored at $-20^{\circ} \mathrm{C}$ until DNA extraction. Total DNA was extracted from these leaves using the DNeasy 96 Plant Kit (Qiagen, Hilden, Germany). Amount and quality of the DNA were analyzed by $1 \%$ agarose gel electrophoresis with 1 XTAE as running buffer. DNA was stained with ethidium bromide or Roti-Safe GelStain (Roth, Karlsruhe, Germany), visualized by UV illumination and compared to a Lambda DNA size marker (Roche, Mannheim, Germany).

\section{Microsatellite analysis}

The microsatellite analysis was conducted as described in Müller et al. (2015). Briefly, nine highly polymorphic microsatellite markers were used (FS3-04, Pastorelli et al. (2003); mfs11, Vornam et al. (2004); sfc0018, sfc0161, sfc1063, sfc1143, Asuka et al. (2004); EST markers GOT066, FIR065, FIR004, Durand et al. (2010)), and the primers were pooled into three different sets for multiplexing (set1: all sfc loci, set 2: FS 3-04 and mfs 11, set 3: GOT066, FIR065, FIR004). After PCR, the microsatellite fragments were separated on an ABI PRISM 3100 Genetic Analyzer (Applied Biosystems, Foster City, USA). Scoring of fragments was conducted with the Genotyper 3.7 software (Applied Biosystems, Foster City, USA).

\section{Data analysis}

\section{Adaptive data}

Provenances were tested for differences in seedling height and seedling height increment using linear mixed-effects models ("Imer" function in the Ime4 R package (Bates et al. 2015)), with seedling height or seedling height increment as response variable, provenances as fixed effect, and blocks and provenanceblock interactions as random effects. Non-significant interactions were excluded from the model. The "glht" function within the "multcomp" R package (Hothorn et al. 2008) with Tukey`s post hoc test was applied to detect differences among provenances. A false discovery rate (FDR) threshold of 0.05 was applied to correct for multiple testing. Differences between the mortality rate of the provenances were tested using generalized mixed-effects models ("glmer" function in the Ime4 R package (Bates et al. 2015)) with a binomial distribution. Mortality was the response variable, provenances were fixed effects, and blocks and provenance-block interactions were random effects in the model. Non-significant interactions were excluded from the model. Differences among provenances were determined using the "glht" function as described above with the same FDR threshold. Model assumptions were checked visually using diagnostic plots of residuals. Spearman's rank correlation coefficient was used to determine correlations between the traits "mortality", "height" and "height increment" with the environmental conditions at the provenance origins 
"mean annual precipitation","mean precipitation in the vegetation period", "mean annual temperature", "mean temperature in the vegetation period", and "water storage capacity in the mineral soil" (Table 1). All statistical analyses were conducted in R 3.3.1 (R Core Team 2016). Boxplots for seedling height and seedling height increment were created with STATISTICA version 13 (Dell Inc., Round Rock, USA).

\section{Microsatellites}

Linkage disequilibrium, frequency of null alleles, and Hardy-Weinberg proportions were estimated using the Genepop 4.2.1 software (Rousset 2008) based on SSR data of the adult provenances and seedlings. Markov chain parameters for the test of linkage disequilibrium and deviations from Hardy-Weinberg equilibrium were the following: 10,000 demorization steps, 100 batches and 5,000 iterations per batch. For the seedlings the genetic diversity indices number of alleles $\left(\mathrm{N}_{\mathrm{a}}\right)$, observed heterozygosity $\left(\mathrm{H}_{\mathrm{o}}\right)$, expected heterozygosity $\left(\mathrm{H}_{\mathrm{e}}\right)$ and fixation index (F) were estimated using the GenAlEx 6.501 software (Peakall and Smouse 2006, Peakall and Smouse 2012). A Kruskal-Wallis test with multiple comparisons implemented in the STATISTICA 13 software (Dell Inc., Round Rock, USA) was used to compare these parameters with previously obtained data from the adult provenances (origin of the seedlings; (Seifert 2012)). Additionally, to test the representativity of the seedlings for the adult provenances, an Unweighted Pair Group Method with Arithmetic Mean (UPGMA) dendrogram, based on Nei's distance (Nei 1972) was calculated using the "populations" 1.2.32 software (Langella 1999). Bootstrap values based on 1,000 permutations were also calculated with this program. The dendrogram was visualized with the TreeView 1.6 .6 software (Page 1996) using the phylogram tree style. Pairwise $G_{S T}$ among (Nei 1987, Meirmans and Hedrick 2011) adult provenances was calculated with GenAIEx 6.501 (Peakall and Smouse 2006, Peakall and Smouse 2012) using 999 permutations for the significance test. The Bayesian model-based clustering method implemented in the STRUCTURE 2.3.3 software (Pritchard et al. 2000) was applied to infer population structure among adult provenances. The no admixture model and correlated allele frequencies were selected. A burn-in period of 10,000 and Markov chain Monte Carlo (MCMC) replicates of 100,000 were used. Potential clusters $(K)$ from one to ten were tested using ten iterations. The $\Delta K$ method by (Evanno et al. 2005) was applied to determine the optimal value of $K$ using the STRUCTURE HARVESTER 0.6.93 program (Earl and vonHoldt 2012).

\section{Results}

\section{Seedling adaptive traits}

At planting, several provenances showed significantly different heights, whereby the median ranged from $11.0 \mathrm{~cm}$ for the provenances $\mathrm{Ha}, \mathrm{CL}$ and $\mathrm{GL}$ to $14 \mathrm{~cm}$ for the provenance GS (Fig. 2a). In fall 2011, the median height ranged from $22.0 \mathrm{~cm}$ for the provenance CL to $25.5 \mathrm{~cm}$ for the provenance GS and US (Fig. 2b). In 2012 the provenances $C L$ and GL showed the smallest
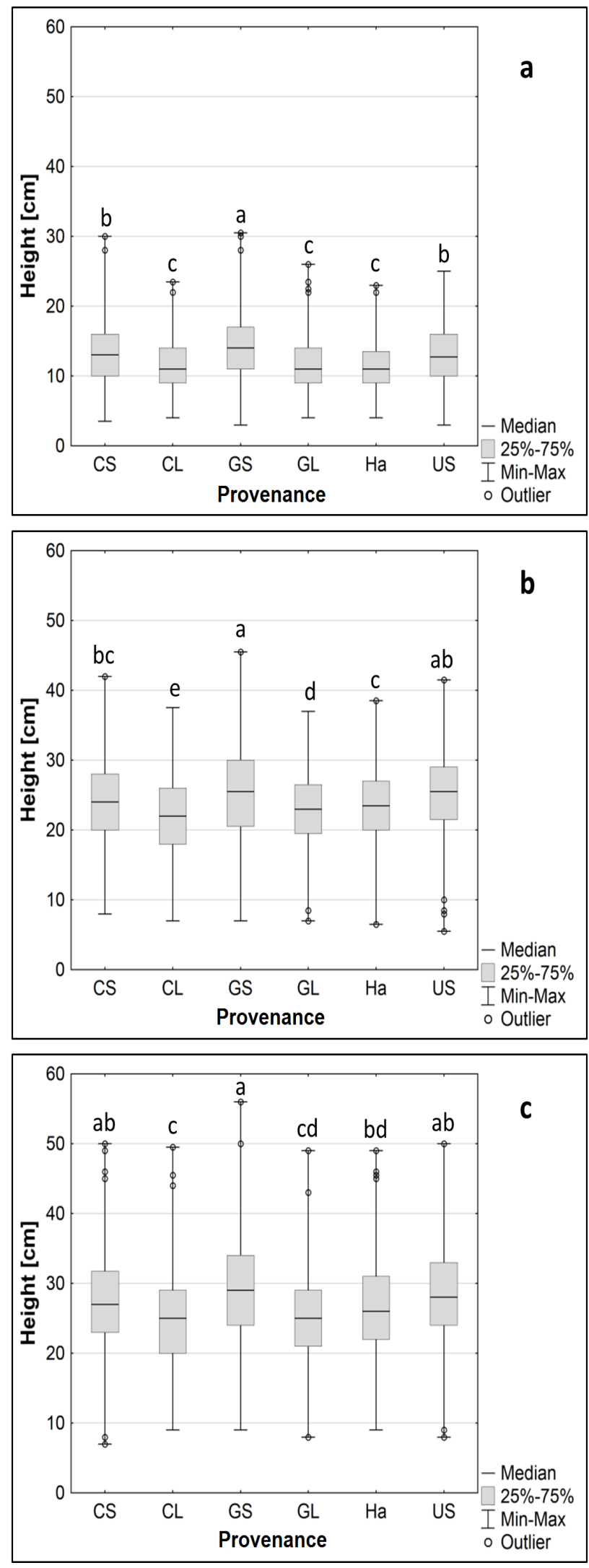

Fig. 2

Seedling height of the provenances in the common garden experiment at planting (2010) (a), the year 2011 (b), and the year 2012 (c). Different letters indicate significant differences among provenances $(p<0.05)$ 


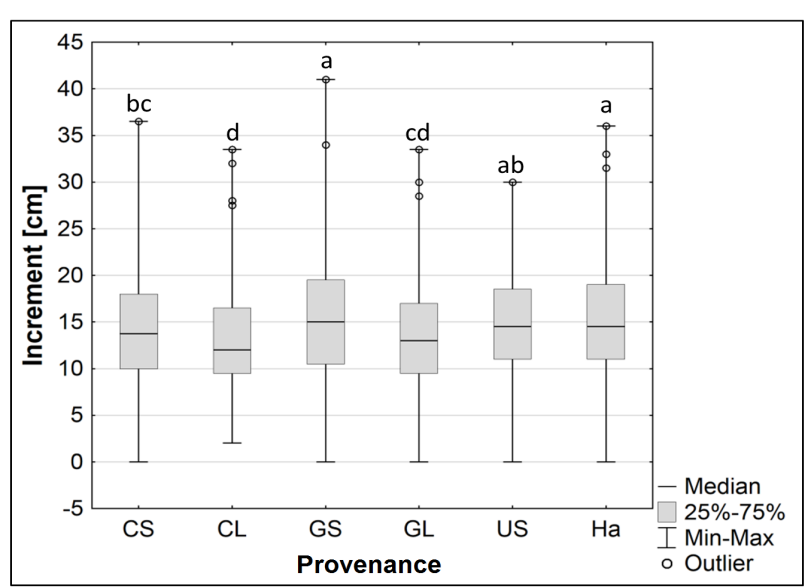

Fig. 3

Mean increment of the beech provenances in the common garden experiment from establishment (2010) to fall 2012. Different letters indicate significant differences among provenances $(p<0.05)$

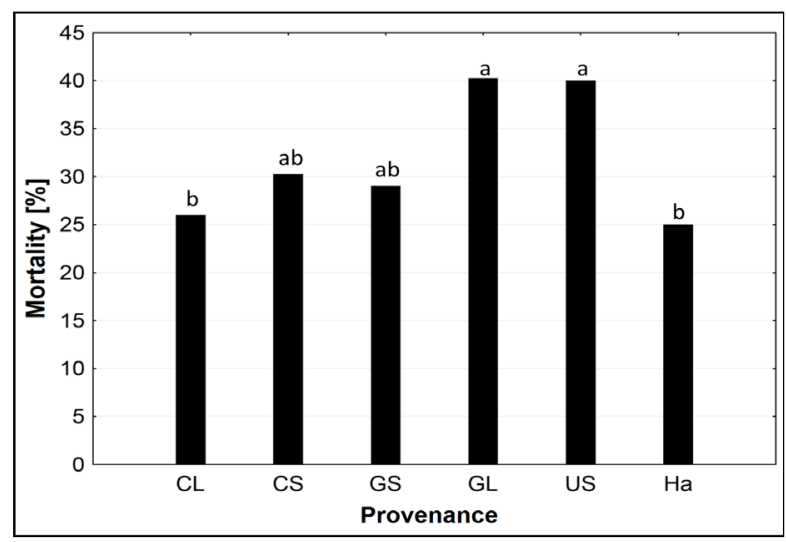

Fig. 4

Mortality rate [\%] of the beech provenances in the common garden experiment in the year 2013. Different letters indicate significant differences among provenances $(p<0.05)$

seedlings (median: $25 \mathrm{~cm}$ ), whereas the provenance GS showed the largest seedlings (median $29.0 \mathrm{~cm}$ ) (Fig. 2c).

Also the seedling increment differed between the provenances (Fig. 3), whereby the provenances GS and Ha showed the highest increment (median: $15.3 \mathrm{~cm}$ ) during the observation period from the establishment of the experiment (2010) to fall 2012. The lowest increment was observed for the provenance $C L$ (median: $13.1 \mathrm{~cm}$ ). In early summer 2011, only a few seedlings (1-4) per provenance did not survive. In 2012, the mean mortality rate was low ( $8.2 \%$ ) but significantly different between the provenances. The highest mortality was observed for the provenance US (12.3\%) and the lowest one for the provenance GS (4.3\%). In the following year (2013) (Fig. 4), the mean mortality rate was $31.8 \%$ and, hence, clearly higher than in 2012 and still significantly different between provenances. The highest mortality was recorded for the provenances US (40\%) and GL (40.3\%). The lowest mortality was found for the provenance $\mathrm{Ha}(25 \%)$. No statistically significant correlations were found between adaptive traits and the environmental conditions at the provenance origins.

\section{Linkage disequilibrium, Hardy-Weinberg equilibri- um, and null alleles}

Significant linkage disequilibrium $(p<0.05)$ was observed for the markers in the different adult provenances and seedlings (Supplementary Material 2). No LD was found for the adult provenance CS and the seedlings of provenance GS, whereas the highest amount of LD was estimated for the adult provenance $\mathrm{Ha}$ (19.4\%). Based on the complete set of SSR loci, deviations from Hardy-Weinberg proportions were revealed only for the adult provenances $\mathrm{Ha}$ and GS, and the seedlings of the provenance Ha. Single SSR loci that showed deviations from HardyWeinberg proportions were sfc0161 (for the adult provenance US), sfc1063 (for the juvenile provenance Ha), FIR065 (for the juvenile provenances CL and CS), FIR004 (for the juvenile provenances $\mathrm{GS}$ and $\mathrm{Ha}$, and the adult provenances GS, UL, and $\mathrm{Ha}$ ), FS3-04 (for the juvenile and adult provenances US), and GOT066 (for the adult provenance GS).

The mean estimated null allele frequency was $3.6 \%$ for the juvenile and $3.7 \%$ for the adult provenances (Supplementary Material 3).

\section{Genetic diversity indices}

Genetic diversity indices differed between the different SSR loci, whereas the two EST-markers "GOT066" and "FIR004" as well as the locus "FS 3-04" showed lower diversity values than the remaining markers (Table 2). Only slight differences for the genetic diversity indices were observed between the different provenances (Table. 3). The mean number of alleles was 8.2. The observed heterozygosity ranged from 0.571 (US) to 0.624 $(\mathrm{Ha})$, and the expected heterozygosity ranged from 0.586 (US) to $0.635(\mathrm{Ha})$. The mean fixation index was 0.015 . No statistically significant differences between the adult and juvenile provenances for the genetic diversity indices were detected.

\section{Genetic differentiation and population structure}

An UPGMA analysis was conducted to test the representativity of the seedlings for the adult provenances. All seedlings grouped together with the respective adult provenance of origin in the dendrogram (Fig. 5). The bootstrap values ranged from 56 $\%$ for the group GS_adult and GS_juvenile and $100 \%$ for the group $\mathrm{CL}_{\text {_adult }}$ and $\mathrm{CL}$ _juvenile.

$\mathrm{G}_{\mathrm{ST}}$ values among the adult provenances ranged from 0.002 between $C S$ and $G S$, and 0.018 between $C L$ and $U S$, and $C L$ and $\mathrm{GL}$, respectively (Table 4). The mean distance between the provenances was 0.010 . The STRUCTURE analysis revealed weak population structure among the different adult provenances, whereby the provenances US and UL were most differentiated from the other provenances (Fig. 6). The $\Delta K$ method (Evanno et al. 2005) revealed an optimal value of $K=2$ (Supplementary Material 4). 
Table 2

Genetic diversity indices for the investigated SSR loci over all analyzed seedlings of the different provenances, $\mathrm{N}_{a}$ : number of alleles, $\mathrm{H}_{\mathrm{o}}$ : observed heterozygosity, $\mathrm{H}_{\mathrm{e}}$ : expected heterozygosity, F: fixation index

\begin{tabular}{lcccc}
\hline Locus & $\mathrm{N}_{\mathrm{a}}$ & $\mathrm{H}_{\mathrm{o}}$ & $\mathrm{H}_{\mathrm{e}}$ & $\mathrm{F}$ \\
\hline sfc0018 & 10.3 & 0.736 & 0.731 & -0.006 \\
sfc0161 & 15.7 & 0.809 & 0.811 & 0.002 \\
sfc1063 & 10.0 & 0.787 & 0.802 & 0.017 \\
sfc1143 & 10.8 & 0.762 & 0.764 & 0.003 \\
GOT066 & 3.2 & 0.145 & 0.135 & -0.066 \\
FIR065 & 4.0 & 0.674 & 0.692 & 0.024 \\
FIR004 & 7.8 & 0.522 & 0.600 & 0.130 \\
FS 3-04 & 3.8 & 0.299 & 0.308 & 0.040 \\
mfs11 & 8.2 & 0.724 & 0.716 & -0.013 \\
\hline
\end{tabular}

Table 3

Genetic diversity indices for the seedlings of the different provenances, $\mathrm{N}$ : number of individuals, $\mathrm{N}_{\mathrm{a}}$ : number of alleles, $\mathrm{H}_{\mathrm{o}}$ : observed heterozygosity, $\mathrm{H}_{\mathrm{e}}$ : expected heterozygosity, $\mathrm{F}$ : fixation index

\begin{tabular}{lccccc}
\hline Provenance & $\mathrm{N}$ & $\mathrm{N}_{\mathrm{a}}$ & $\mathrm{H}_{\mathrm{o}}$ & $\mathrm{H}_{\mathrm{e}}$ & $\mathrm{F}$ \\
\hline $\mathrm{CL}$ & 100 & 8.2 & 0.594 & 0.603 & 0.009 \\
$\mathrm{CS}$ & 99 & 8.4 & 0.621 & 0.633 & 0.012 \\
$\mathrm{GL}$ & 100 & 7.9 & 0.615 & 0.626 & 0.012 \\
$\mathrm{GS}$ & 100 & 8.6 & 0.613 & 0.623 & 0.010 \\
$\mathrm{US}$ & 100 & 7.9 & 0.571 & 0.586 & 0.043 \\
$\mathrm{Ha}$ & 99 & 8.2 & 0.624 & 0.635 & 0.002 \\
Mean & 99.7 & 8.2 & 0.606 & 0.618 & 0.015 \\
\hline
\end{tabular}

Table 4

$G_{\text {ST }}$ values (Meirmans and Hedrick 2011, Nei 1987) among the analyzed adult provenances (in bold, below the diagonal). P-values are shown above the diagonal

\begin{tabular}{cccccccc}
\hline $\mathrm{CL}$ & $\mathrm{CS}$ & $\mathrm{GL}$ & $\mathrm{GS}$ & $\mathrm{Ha}$ & $\mathrm{US}$ & $\mathrm{UL}$ & \\
\hline $\mathbf{0 . 0 0 0}$ & 0.001 & 0.001 & 0.001 & 0.001 & 0.001 & 0.001 & $\mathrm{CL}$ \\
0.012 & 0.000 & 0.001 & 0.010 & 0.001 & 0.001 & 0.001 & $\mathrm{CS}$ \\
0.018 & 0.007 & 0.000 & 0.001 & 0.001 & 0.001 & 0.001 & $\mathrm{GL}$ \\
0.011 & 0.002 & 0.007 & 0.000 & 0.001 & 0.001 & 0.001 & $\mathrm{GS}$ \\
$\mathbf{0 . 0 1 2}$ & 0.005 & 0.011 & 0.005 & 0.000 & 0.001 & 0.001 & $\mathrm{Ha}$ \\
$\mathbf{0 . 0 1 8}$ & 0.011 & 0.014 & 0.014 & 0.012 & 0.000 & 0.001 & $\mathrm{US}$ \\
$\mathbf{0 . 0 1 2}$ & 0.007 & 0.014 & 0.009 & 0.007 & 0.003 & 0.000 & $\mathrm{UL}$ \\
\hline
\end{tabular}

\section{Adaptive trait differentiation}

Significant differences for all analyzed adaptive traits were found for the provenances in the common garden experiment. This is in agreement with data from other studies which also detected variation in plant height, height increment, and mortality among beech provenances (von Wühlisch et al. 2008, Liesebach 2012). Interestingly, the performance of seedlings from lower precipitation environments was not better than that of seedlings from higher precipitation environments. This is unexpected, since the common garden experiment was located in an area near to the lower precipitation limit of beech and there occurred even a dry period from March to May 2011 at the common garden site (Müller-Haubold et al. 2013). Knutzen et al. (2017) and Nguyen et al. (2017) also did not find an influence of precipitation at provenance origins on the growth rate of saplings in a drought stress experiment using saplings from partly the same provenances as here, despite differences in drought response among provenances. Nevertheless, we did not measure drought stress parameters or below ground biomass, and therefore the level of drought stress possibly 


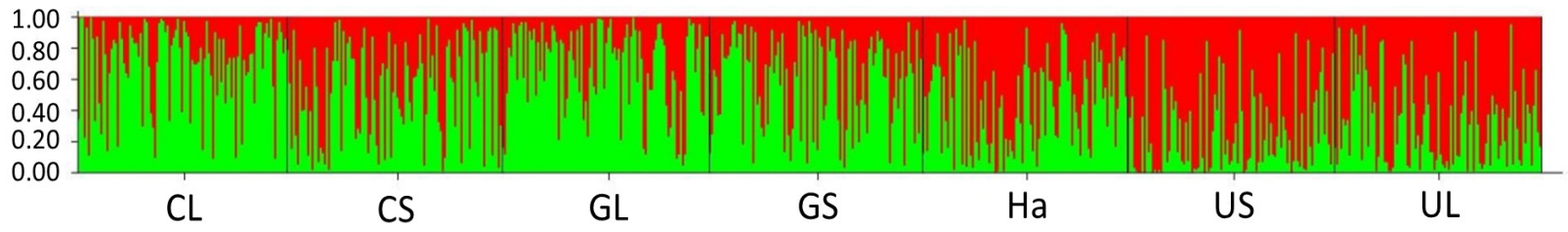

Fig. 6

Clustering of individuals of the different adult provenances assuming $K=2$. Vertical bars indicate the assignment probability of each individual to the two inferred clusters

affecting the seedlings is unknown. Further, no significant correlations were found between the adaptive traits and the environmental conditions on the original provenance sites. Likely, more provenances would be necessary to conduct more robust correlation analyses.

Interestingly, neighboring provenances did not present more similar adaptive trait variation than distant provenances. For instance, the provenance GS showed a significantly larger height, height increment, and an earlier bud burst (Müller et al. 2015) than the neighboring provenance $G L$, which grows only $5 \mathrm{~km}$ apart. Also the mortality rate between the two provenances was significantly different one year after planting. In the second year there was still a difference of $11.3 \%$ between GS and GL, albeit statistically not significant. These results may be explained by different soil properties of the provenances, at least for height and height increment, since there was a trend of better growth of provenances from sandy soils than for loamy soils (Figs. 2 and 3). Nevertheless, for the mortality rate this trend was not observed and other studies that analyzed the same provenances found only minor soil influence on several traits such as fine root biomass, total fine root surface area, fine root production, forest net primary production, wood production, leaf production, fruit mass production, mean annual ring width, or mean sensitivity of growth (Hertel et al. 2013, Müller-Haubold et al. 2013, Knutzen et al. 2017). Flowering conditions, stand density or weather conditions can influence the genetic structure of seeds due to alterations of the mating system, which may lead to differences in the genetic composition of seeds among years (Konnert and Behm 1999). Hence, different genetic structures of neighboring adult provenances during their establishment could be another explanation for the observed differences.

There are some practical limitations using field experiments. For instance, it was not possible to conduct height measurements as precisely as under controlled conditions. Different planting depths of the seedlings and irregularities of the soil surface might have caused some variations. Nevertheless, the high number of seedlings and the block design of the experiment should have effectively mitigated these inaccuracies. The results of the first year measurements might have been influenced by a planting shock. Later measurements however, should show genotypic differences among provenances. It is known that stress resistance increases with ontogeny (Niinemets 2010) and that the increment of beech differs between juvenile age stages (Liesebach 2012). The mortality rate increased with the duration of the common garden experiment from
2011 to 2013, most likely due to an accumulation of stress over time affecting not adapted seedlings. Thus, long-term observations of the common garden experiment would provide more insights into the development of the seedlings from the different provenances. Nevertheless, despite their long lifetime, the most vulnerable phase of trees remains their seedling and sapling stage (Gray et al. 2011). Hence, information about the performance of seedlings from different provenances in this early life stage is of great importance.

\section{Genetic diversity, differentiation and population structure}

All analyzed provenances in this study exhibited a high genetic variation within provenances (mean $\mathrm{H}_{0}$ : 0.606; mean $\mathrm{H}_{\mathrm{e}}$ : 0.618), with no statistically significant differences between adult provenances and seedlings. High genetic diversity based on SSRs was also revealed by other studies of beech (Vornam et al. 2004, $\mathrm{H}_{\mathrm{e}}: 0.765$; Oddou-Muratorio et al. 2011, $\mathrm{H}_{\mathrm{e}}: 0.72$; Bilela et al. 2012, $\mathrm{H}_{\mathrm{e}}:$ 0.777; Rajendra et al. 2014, $\mathrm{H}_{\mathrm{e}}:$ 0.622), and can be expected for outcrossing, wind-pollinated (tree) species (Hamrick et al. 1992, Hamrick and Godt 1996, Petit and Hampe 2006). A high genetic diversity is a good basis for adaptation. Beech forests with a wide genetic basis are more likely to be able to cope with warmer and drier conditions, and thus, to adapt to new environmental conditions (Bilela et al. 2012). However, in light of rapid climate change, gene flow from better adapted populations or the use of assisted migration might be necessary (Jump and Peñuelas 2005, Jump et al. 2006, Gray et al. 2011). All juvenile provenances grouped to the corresponding source provenances in the UPGMA dendrogram supported by high bootstrap values. These results suggest a good sampling design and no influence of the treatment of the seedlings in the greenhouse on their genetic structure. Nevertheless, adult provenances were used to get a precise impression of population structure and differentiation among the analyzed provenances in Northern Germany. The neutral genetic structure among provenances was low, albeit statistically significant (mean $\mathrm{G}_{\mathrm{ST}}$ 0.010, $\mathrm{p}<0.01$ ). Only the provenances US and UL were slightly higher differentiated from the others as referred by the STRUCTURE analysis (Fig. 6). A low population structure of beech in Central Europe was also detected by other studies (e.g., (Demesure et al. 1996, Magri et al. 2006, Lalagüe et al. 2014, Rajendra et al. 2014). Departures from the model assumptions in the STRUCTURE software (Hardy-Weinberg equilibrium within populations and linkage equilibrium 
between loci within populations (Pritchard et al. 2000)) can lead to an overestimation of $K$. Since only $8.3 \%$ of all SSR markers were in LD over all adult provenances and only two adult provenances showed deviations from Hardy Weinberg equilibrium, a reliable analysis of population structure is expected. The estimated null allele frequency for the investigated SSR loci was $3.6 \%$ for the juvenile and $3.7 \%$ for the adult provenances. Population genetic parameters seem to be mostly unbiased for null-allele frequencies ranging between $5 \%$ and $8 \%$ on average across loci (Oddou-Muratorio et al. 2009). Thus, although some loci may be affected by null alleles, a reliable population genetic analysis can be assumed in our study.

\section{Conclusions}

This study aimed to determine adaptive trait and genetic variation of beech provenances on a regional scale in Northern Germany. Significant differences in the performance of the provenances were detected for all analyzed traits. No influence of precipitation at provenance origins was detected on the performance of the provenances at the common garden site located near the lower precipitation limit of beech. Furthermore, even neighboring provenances presented more different adaptive trait variation than distant provenances. Indeed, a long-term study would be required to assess the future development of the provenances. A high genetic diversity within and only minor population structure among provenances was detected, which can be assumed to be a good basis for adaptation. Nevertheless, these results are based on neutral genetic markers, and future studies should also take adaptive genetic variation into account.

\section{Acknowledgement}

We thank the late Dr. Sarah Seifert for providing SSR data of the adult beech populations, and her scientific support during the study. We thank A. Dolynska, C. Radler, G. Dinkel and A. Capelle for their technical assistance as well as all persons who helped us with the field work. We thank C Döring for the regionalization of the precipitation and temperature data. The study was supported by the Ministry for Science and Culture of Lower Saxony within the network KLIFF - climate impact and adaptation research in Lower Saxony.

\section{References}

Asuka Y, Tani N, Tsumura Y, Tomaru N (2004) Development and characterization of microsatellite markers for Fagus crenata Blume. Mol Ecol Notes 4 (1):101103. https://doi.org/10.1046/j.1471-8286.2003.00583.x

Bates D, Mächler M, Bolker B, Walker S (2015) Fitting linear mixed-effects models using Ime4. J Stat Softw 67 (1):48. https://doi.org/10.18637/jss.v067.i01

Bilela S, Dounavi A, Fussi B, Konnert M, Holst J, Mayer H, Rennenberg H, Simon J (2012) Natural regeneration of Fagus sylvatica L. adapts with maturation to warmer and drier microclimatic conditions. For Ecol Manag 275:60-67. https://doi.org/10.1016/j.foreco.2012.03.009

Charru M, Seynave I, Morneau F, Bontemps JD (2010) Recent changes in forest productivity: An analysis of national forest inventory data for common beech (Fagus sylvatica L.) in north-eastern France. For Ecol Manag 260 (5):864-874. https://doi.org/10.1016/j.foreco.2010.06.005

Demesure B, Comps B, Petit RJ (1996) Chloroplast DNA phylogeography of the common beech (Fagus sylvatica L) in Europe. Evolution 50 (6):2515-2520. https://doi.org/10.2307/2410719

Dounavi A, Netzer F, Celepirovic N, Ivanković M, Burger J, Figueroa AG, Schön S, Simon J, Cremer E, Fussi B, Konnert M, Rennenberg H (2016) Genetic and physiological differences of European beech provenances (F. sylvatica L.) exposed to drought stress. For Ecol Manag 361:226-236. https://doi. org/10.1016/j.foreco.2015.11.014

Durand J, Bodenes C, Chancerel E, Frigerio JM, Vendramin G, Sebastiani F, Buonamici A, Gailing O, Koelewijn HP, Villani F, Mattioni C, Cherubini M, Goicoechea PG, Herran A, Ikaran Z, Cabane C, Ueno S, Alberto F, Dumoulin PY, Guichoux E, de Daruvar A, Kremer A, Plomion C (2010) A fast and cost-effective approach to develop and map EST-SSR markers: oak as a case study. BMC Genomics 11:570. https://doi.org/10.1186/1471-2164-11-570

Earl DA, vonHoldt BM (2012) STRUCTURE HARVESTER: a website and program for visualizing STRUCTURE output and implementing the Evanno method. Conserv Genet Resour 4 (2):359-361. https://doi.org/10.1007/s12686-0119548-7

Evanno G, Regnaut S, Goudet J (2005) Detecting the number of clusters of individuals using the software STRUCTURE: a simulation study. Mol Ecol 14 (8):2611-2620. https://doi.org/10.1111/j.1365-294x.2005.02553.x

Gray LK, Gylander T, Mbogga MS, Chen PY, Hamann A (2011) Assisted migration to address climate change: recommendations for aspen reforestation in western Canada. Ecol Appl 21 (5):1591-1603. https://doi.org/10.1890/101054.1

Hamrick JL, Godt MJW, Sherman-Broyles SL (1992) Factors influencing levels of genetic diversity in woody plant species. New Forest 6 (1-4):95-124 https:// doi.org/10.1007/bf00120641

Hamrick JL, Godt MJW (1996) Effects of life history traits on genetic diversity in plant species. Philos T Roy Soc B 351 (1345):1291-1298. https://doi.org/ 10.1098/rstb.1996.0112

Hanewinkel M, Cullmann DA, Schelhaas M-J, Nabuurs G-J, Zimmermann NE (2013) Climate change may cause severe loss in the economic value of European forest land. Nat Clim Change 3 (3):203-207. https://doi.org/10.1038/ nclimate1687

Hertel D, Strecker T, Müller-Haubold H, Leuschner C, Guo D (2013) Fine root biomass and dynamics in beech forests across a precipitation gradient - is optimal resource partitioning theory applicable to water-limited mature trees? J Ecol 101 (5):1183-1200. https://doi.org/10.1111/1365-2745.12124

Hofmann M, Durka W, Liesebach M, Bruelheide H (2015) Intraspecific variability in frost hardiness of Fagus sylvatica L. Eur J For Res 134 (3):433-441. https:// doi.org/10.1007/s10342-015-0862-6

Hothorn T, Bretz F, Westfall P (2008) Simultaneous inference in general parametric models. Biometrical J 50 (3):346-363. https://doi.org/10.1002/bimj. $\underline{200810425}$

Jump AS, Peñuelas J (2005) Running to stand still: adaptation and the response of plants to rapid climate change. Ecol Lett 8 (9):1010-1020. https://doi. org/10.1111/j.1461-0248.2005.00796.x

Jump AS, Hunt JM, Martinez-Izquierdo JA, Penuelas J (2006) Natural selection and climate change: temperature-linked spatial and temporal trends in gene frequency in Fagus sylvatica. Mol Ecol 15 (11):3469-3480. https://doi. org/10.1111/j.1365-294x.2006.03027.x

Knapp HD, Emde F-A, Engels B, Lehrke S, Hendrischke O, Klein M, Kluttig H, Krug A, Schäfer H-J, Scherfose V, Schröder E, Schweppe-Kraft B (2008) Naturerbe Buchenwälder: Situationsanalyse und Handlungserfordernisse. Bonn, Vilm: Bundesamt für Naturschutz

Knutzen F, Dulamsuren C, Meier IC, Leuschner C (2017) Recent climate warming-related growth decline impairs European beech in the center of its distribution range. Ecosystems. https://doi.org/10.1007/s10021-017-0128-x

Konnert M, Behm A (1999) Genetische Strukturen einer Saatgutpartie - Einflussfaktoren und Einflussmöglichkeiten. Beiträge für Forstwirtschaft und Landschaftsökologie 33:152-156

Lalagüe H, Csilléry K, Oddou-Muratorio S, Safrana J, de Quattro C, Fady B, González-Martínez SC, Vendramin GG (2014) Nucleotide diversity and linkage disequilibrium at 58 stress response and phenology candidate genes in a European beech (Fagus sylvatica L.) population from southeastern France. Tree Genet Genomes 10 (1):15. https://doi.org/10.1007/s11295-013-0658-0 Langella O (1999) Populations version 1.2.32 [online]. To be found in <http:// www.bioinformatics.org/project/?group id=84> 
Liesebach M (2012) Wachstum und phänotypische Variation von sechs Herkünften der Rot-Buche (Fagus sylvatica L.) an einem Standort in Schleswig-Holstein. Appl Agric Forestry Res 62:179-192

Magri D, Vendramin GG, Comps B, Dupanloup I, Geburek T, Gömöry D, Latalowa M, Litt T, Paule L, Roure JM, Tantau I, van der Knaap WO, Petit RJ, de Beaulieu $J \mathrm{~L}$ (2006) A new scenario for the quaternary history of European beech pop ulations: palaeobotanical evidence and genetic consequences. New Phytol 171 (1):199-221. https://doi.org/10.1111/j.1469-8137.2006.01740.x

Meier ES, Edwards Jr TC, Kienast F, Dobbertin M, Zimmermann NE (2011) Co-occurrence patterns of trees along macro-climatic gradients and their potential influence on the present and future distribution of Fagus sylvatica L. J Biogeogr 38 (2):371-382. https://doi.org/10.1111/j.1365-2699.2010.02405.x

Meirmans PG, Hedrick PW (2011) Assessing population structure: F(ST) and related measures. Mol Ecol Resour 11 (1):5-18. https://doi.org/10.1111/j.1755 0998.2010.02927.x

Müller-Haubold H, Hertel D, Seidel D, Knutzen F, Leuschner C (2013) Climate responses of aboveground productivity and allocation in Fagus sylvatica: a transect study in mature forests. Ecosystems 16 (8):1498-1516. https://doi. org $/ 10.1007 / \mathrm{s} 10021-013-9698-4$

Müller M, Seifert S, Finkeldey R (2015) A candidate gene-based association study reveals SNPs significantly associated with bud burst in European beech (Fagus sylvatica L.). Tree Genet Genomes 11 (6):116. https://doi. org/10.1007/s11295-015-0943-1

Nei M (1972) Genetic Distance between Populations. Am Nat 106 (949):283-292. https://doi.org/10.1086/282771

Nei M (1987) Molecular Evolutionary Genetics. New York: Columbia University Press. https://doi.org/10.1016/0047-2484(89)90093-6

Nguyen QN, Polle A, Pena R (2017) Intraspecific variations in drought response and fitness traits of beech (Fagus sylvatica L.) seedlings from three provenances differing in annual precipitation. Trees. https://doi.org/10.1007/ s00468-017-1539-1

Niinemets Ü (2010) Responses of forest trees to single and multiple environmental stresses from seedlings to mature plants: Past stress history, stress interactions, tolerance and acclimation. For Ecol Manag 260 (10):1623-1639. https://doi.org/10.1016/j.foreco.2010.07.054

Oddou-Muratorio S, Vendramin GG, Buiteveld J, Fady B (2009) Population estimators or progeny tests: what is the best method to assess null allele frequencies at SSR loci? Conserv Genet 10 (5):1343-1347. https://doi.org/10. 1007/s10592-008-9648-4

Oddou-Muratorio S, Klein EK, Vendramin GG, Fady B (2011) Spatial vs. temporal effects on demographic and genetic structures: the roles of dispersal, masting and differential mortality on patterns of recruitment in Fagus sylvatica. Mol Ecol 20 (9):1997-2010. https://doi.rg/10.1111/j.1365-294x.2011.05039.x

Page RD (1996) TreeView: an application to display phylogenetic trees on personal computers. Comput Appl Biosci 12 (4):357-358. https://doi.org/10. 1093/bioinformatics/12.4.357

Pastorelli R, Smulders MJM, Van't Westende WPC, Vosman B, Giannini R, Vettori C, Vendramin GG (2003) Characterization of microsatellite markers in Fagus sylvatica L. and Fagus orientalis Lipsky. Mol Ecol Notes 3 (1):76-78. https:// doi.org/10.1046/j.1471-8286.2003.00355.x

Peakall R, Smouse PE (2006) genalex 6: genetic analysis in Excel. Population genetic software for teaching and research. Mol Ecol Notes 6 (1):288-295. https://doi.org/10.1111/j.1471-8286.2005.01155.x

Peakall R, Smouse PE (2012) GenAIEx 6.5: genetic analysis in Excel. Population genetic software for teaching and research--an update. Bioinformatics 28 (19):2537-2539. https://doi.org/10.1093/bioinformatics/bts460

Peñuelas J, Boada M (2003) A global change-induced biome shift in the Montseny mountains (NE Spain). Glob Change Biol 9 (2):131-140. https://doi. org/10.1046/j.1365-2486.2003.00566.x

Petit RJ, Hampe A (2006) Some evolutionary consequences of being a tree. Annu Rev Ecol Evol S 37 (1):187-214. https://doi.org/10.1146/annurev.ecolsys.37.091305.110215

Pluess AR, Weber P (2012) Drought-adaptation potential in Fagus sylvatica: linking moisture availability with genetic diversity and dendrochronology. PLoS One 7 (3):e33636. https://doi.org/10.1371/journal.pone.0033636

Pluess AR, Frank A, Heiri C, Lalague H, Vendramin GG, Oddou-Muratorio S (2016) Genome-environment association study suggests local adaptation to cli- mate at the regional scale in Fagus sylvatica. New Phytol 210 (2):589-601. https://doi.org/10.1111/nph.13809

Pritchard JK, Stephens M, Donnelly P (2000) Inference of population structure using multilocus genotype data. Genetics 155 (2):945-959

R Core Team (2016) R: A language and environment for statistical computing [online]. To be found in <http://www.R-project.org/>

Rajendra KC, Seifert S, Prinz K, Gailing O, Finkeldey R (2014) Subtle human impacts on neutral genetic diversity and spatial patterns of genetic variation in European beech (Fagus sylvatica). For Ecol Manag 319:138-149. https:// doi.org/10.1016/j.foreco.2014.02.003

Robson TM, Sánchez-Gómez D, Cano FJ, Aranda I (2012) Variation in functional leaf traits among beech provenances during a Spanish summer reflects the differences in their origin. Tree Genet Genomes 8 (5):1111-1121. https://doi. org/10.1007/s11295-012-0496-5

Rose L, Leuschner C, Köckemann B, Buschmann H (2009) Are marginal beech (Fagus sylvatica L.) provenances a source for drought tolerant ecotypes? Eur J For Res 128 (4):335-343. https://doi.org/10.1007/s10342-009-0268-4

Rousset F (2008) genepop'007: a complete re-implementation of the genepop software for Windows and Linux. Mol Ecol Resour 8 (1):103-106. https://doi. org/10.1111/j.1471-8286.2007.01931.x

Scharnweber T, Manthey M, Criegee C, Bauwe A, Schröder C, Wilmking M (2011) Drought matters - Declining precipitation influences growth of Fagus sylvatica L. and Quercus robur L. in north-eastern Germany. For Ecol Manag 262 (6):947-961. https://doi.org/10.1016/j.foreco.2011.05.026

Seifert S (2012) Variation of candidate genes related to climate change in European beech (Fagus sylvatica L.). Göttingen, 134 p, University of Göttingen

Seifert S, Vornam B, Finkeldey R (2012) DNA sequence variation and development of SNP markers in beech (Fagus sylvatica L.). Eur J For Res 131 (6):1761-1770. https://doi.org/10.1007/s10342-012-0630-9

Shorthouse D (2010) SimpleMappr, an online tool to produce publication-quality point maps [online]. To be found in <http://www.simplemappr.net $>$

Tarp P, Helles F, Holten-Andersen P, Larsen JB, Strange N (2000) Modelling near-natural silvicultural regimes for beech - an economic sensitivity analysis. For Ecol Manag 130 (1-3):187-198. https://doi.org/10.1016/s03781127(99)00190-5

Višnjić Ć, Dohrenbusch A (2004) Frost resistance and phenology of European beech provenances (Fagus sylvatica L.). Allg Forst Jagdztg 175:101-108 von Wühlisch G, Krusche D, Muhs HJ (1995) Variation in temperature sum requirement for flushing of beech provenances. Silvae Genet 44:343-346 von Wühlisch G, Hansen JK, Mertens P, Liesebach M, Meierjohann E, Muhs H-J, Teissier du Cros E, de Vries S Terazawa K, Madsen P, Sagheb-Talebi K (eds) Variation among Fagus sylvatica and Fagus orientalis provenances in young international field trials: The organizing committee of the 8th IUFRO international beech symposium c/o Hokkaido Forestry Research Institute Bibai, Hokkaido, Japan

Vornam B, Decarli N, Gailing O (2004) Spatial distribution of genetic variation in a natural beech stand (Fagus sylvatica L.) based on microsatellite markers. Conserv Genet 5 (4):561-570.https://doi.org/10.1023/b:coge.0000041025. 82917.ac 